\title{
Greek Orthodox fasting rituals: a hidden characteristic of the Mediterranean diet of Crete
}

\author{
Katerina O. Sarri*, Manolis K. Linardakis, Frosso N. Bervanaki, Nikolaos E. Tzanakis and \\ Anthony G. Kafatos \\ Department of Social Medicine, University of Crete, School of Medicine, PO Box 2208, Iraklion 71003, Crete, Greece
}

(Received 7 October 2003 - Revised 19 March 2004 - Accepted 12 April 2004)

\begin{abstract}
The longevity and excellent health status of the population of Crete has been attributed to its lifestyle and dietary habits. The impact of Greek Orthodox Christian Church fasting on these dietary habits has never been studied. One hundred and twenty Greek Orthodox Christians living in Crete participated in a 1-year prospective study. One half of the subjects, who fasted regularly (fasters), and sixty non-faster controls were followed longitudinally for the three main fasting periods over 1 year; Christmas (40 d), Lent (48d) and the Assumption (15d). Pre- and end-holy days measurements were performed in each fasting period including: $24 \mathrm{~h}$ dietary recall, blood collection and anthropometric measurements. Based on the $24 \mathrm{~h}$ recall, fasters as compared with controls had lower intakes of end-holy days dietary cholesterol, total fat, saturated fatty acids, trans-fatty acids and protein $(P<0.001)$. Fasters presented a decrease of $753 \mathrm{~kJ}(180 \mathrm{kcal})$ in end-holy days energy intake $(P<0.05)$ compared with an increase of $573 \mathrm{~kJ}(137 \mathrm{kcal})$ in the controls $(P<0 \cdot 05)$. Fasters had a decrease in end-holy days $\mathrm{Ca}$ intake $(P<0.001)$ and an increase in end-holy days total dietary fibre $(P<0.001)$ and folate $(P<0.05)$, attributed to their higher consumption of fruit and vegetables in end-holy periods $(P<0 \cdot 001)$. There were no differences for other vitamins or minerals between pre- and end-holy periods in both groups except for vitamin $\mathrm{B}_{2}$. The Orthodox Christian dietary regulations are an important component of the Mediterranean diet of Crete characterised by low levels of dietary saturated fatty acids, high levels of fibre and folate, and a high consumption of fruit, vegetables and legumes.
\end{abstract}

Orthodox Christians: Fasting: Mediterranean diet

The Mediterranean diet of Crete has been shown to be health promoting and protective for CHD and some types of cancer (Keys, 1980; Keys et al. 1986; Berrino \& Muti, 1989; James et al. 1989). These findings have been confirmed from the Seven Countries Study where the population of Crete had the lowest CHD mortality rate and the longest life expectancy in comparison with the other participating populations (Keys, 1980; Keys et al. 1986; Kromhout et al. 1989).

The diet of Crete in the early 1960s was characterised by the high consumption of wheat-based products, legumes, moderate dairy-product consumption, and an abundance of seasonal fruit and vegetables. In contrast, meat and fish consumption was limited while olive oil and olives were the main fat source (Kafatos \& Mamalakis, 1993). The Seven Countries Study population of Crete came from rural areas of Crete where religious strictures and rituals were deeply embedded in the traditions, customs and lifestyle including dietary habits. Although the Seven Countries Study attributed the excellent health status of the population and the low CHD morbidity and mortality to dietary habits (Menotti et al. 1999), there is no investigation of the impact of Greek Orthodox fasting recommendations on dietary intake. The dietary data of the Seven
Countries Study suggest the important role of Greek Orthodox Church fasting since meat and dairy-product intake was low in the early $1960 \mathrm{~s}$ ( $35 \mathrm{~g}$ meat/d; $124 \mathrm{~g}$ dairy products/d) (Kromhout et al. 1989). The low incomes common to the Crete population in the early 1960s do not totally explain the low meat and dairy-product intake since the majority of the population were small-hold farmers producing their own animal and plant products. During the Greek Orthodox Church fasting periods, animal products are preserved for the non-fasting periods. Apart from the health-promoting effects, these practices had positive benefits in terms of economic and environmental sustainability. Over the last four decades, however, the traditional Cretan diet and lifestyle has been progressively Westernised. One result has been a progressive deterioration in CVD morbidity and mortality rates (Kafatos et al. 1991; Ferro-Luzzi et al. 2002).

There is very limited research in Greece concerning the influence of Greek Orthodox lifestyle principles on Greek health behaviour and dietary habits (Chliaoutakis et al. 1999, 2002; Sarri et al. 2003). The objective of the present study was therefore to investigate nutrient intake and food consumption in a population that adheres closely to Greek Orthodox Christianity's dietary recommendations.

\footnotetext{
Abbreviations: RDA, recommended dietary allowances; SFA, saturated fatty acids.

* Corresponding author: Ms Katerina Sarri, fax + 302810 394604, email katsarri@med.uoc.gr
} 


\section{The Orthodox Church's dietary recommendations}

The Orthodox Church specifies dietary restrictions and a fasting for a total of $180-200 \mathrm{~d}$ annually. The faithful are advised to avoid olive oil, meat, fish, milk, eggs and cheese every Wednesday and Friday, with the exception of the week after Christmas, Easter and the Pentecost. There are three principal fasting periods annually. The first of these is a total of $40 \mathrm{~d}$ preceding Christmas when meat, dairy products and eggs are not allowed, while fish and olive oil are allowed except on Wednesdays and Fridays. The second is a period of $48 \mathrm{~d}$ preceding Easter (Lent). During Lent fish is allowed only on $2 \mathrm{~d}$ (25 March and Palm Sunday) whereas meat, dairy products and eggs are not allowed. Olive oil consumption is allowed only during weekends. Third, there is a total of $15 \mathrm{~d}$ in August (the Assumption) when the same dietary rules apply as for Lent with the exception of fish consumption, which is allowed only on 6 August (Metamorphosis). Seafood such as shrimps, squid, cuttlefish, octopus, lobsters, crabs as well as snails are allowed on all fasting days throughout the year.

\section{Methods}

\section{Subjects}

A total of 120 Greek Orthodox Christian adults from the area of Iraklion-Crete participated in the present study. Sixty of the subjects (thirty-one males, twenty-nine females), mean age 42 (SD 12) years, were faithful fasters who vigorously adhered to all the Orthodox Christian fasting practices and all the recommended fasting periods. In order to find such subjects, three monasteries and one of the archdioceses in Crete were contacted. All nuns, priests and laypersons working in the convents and the archdiocese were informed about the project and those who accepted to participate in the study completed written consent forms. The inclusion criteria were: $20-60$ years of age, adherence to the Christian Orthodox dietary recommendations (fasting), no chronic disease, not taking any medication or dietary supplements. Of the nuns, priests and laypersons contacted who fulfilled the inclusion criteria, $54 \%$ participated in the present study. For the control group an announcement was published in a local newspaper. The first healthy sixty individuals that were Orthodox Christians and fulfilled the same criteria as the fasters group, apart from the criterion of fasting, constituted the control group (twenty-four males, thirty-six females; mean age 38 (SD 9) years). The control group did not fast at all at any period of the year, was in the same age range, suffered from no diseases and did not take any medication or supplements. The family history of each subject was recorded with regard to diabetes, CHD, smoking, hormonal disturbances and drug intake.

\section{Study design}

Three sets of examinations were scheduled during 1 year (2000-2001) to cover the three principal fasting periods: Christmas, Lent, and the Assumption. Each set of examinations comprised two measurement sessions, at the beginning and the end of each fasting period. All measurements were made between 08.00 and 10.00 hours and they included fasting blood collection (biochemical analysis), anthropometric measurements (height, weight, waist:hip ratio, and blood pressure), the completion of questionnaires on fasting, health habits and certain items of personal data. The methods for these measurements are described in a previous publication (Sarri et al. 2003).

\section{Dietary data and food database}

A $24 \mathrm{~h}$ dietary recall and a $3 \mathrm{~d}$ weighed food record were administered to all the subjects in each examination period. A trained dietitian used food-model photographs and household measures for the administration of the $24 \mathrm{~h}$ dietary recall. Approximately $30 \%$ of the total number of $24 \mathrm{~h}$ dietary recalls was administered on Wednesdays and Fridays. Written and oral instructions were provided for completion of the $3 \mathrm{~d}$ weighed food record including two weekdays and one during a weekend. The food items and recipes were categorised into seventeen main food groups: bread, cereals, potatoes, vegetables, pulses, fruit, eggs, cheese, milk and yoghurt, fats, sugar and sugar products, pastries, alcohol, meat, fish, seafood, and all the rest (Table 3).

A comprehensive Greek national food composition database derived from chemically analysed Greek-origin foods is presently under construction. The food database Greek Diet, used to calculate dietary intakes, was initially created in 1990 by the Preventive Medicine and Nutrition Clinic of the University of Crete and later, in 1998, was upgraded using the USDA Nutrient Database for Standard Reference (release 11, 1996; USDA Agricultural Research Service, Washington, DC, USA). An extensive description of the database is given elsewhere (Moschandreas \& Kafatos, 1999; Kafatos et al. 2000).

\section{Statistical analysis}

The paired samples $t$ test was used to evaluate the significance of the mean difference within group between the nutrient intakes reported by the $3 \mathrm{~d}$ weighed food record and the $24 \mathrm{~h}$ dietary recall method, as they were extracted from the mean values of all $24 \mathrm{~h}$ dietary recalls and $3 \mathrm{~d}$ food records gathered. The subjects included in this analysis had at least one pre-holy days and one end-holy days measurement. Analysis of covariance was used to examine the differences in nutrient intakes between the two groups, adjusting for sex, age and baseline BMI; the Mann-Whitney test was used to investigate the differences in food consumption between the two groups. Individual recommended dietary allowances (RDA) or dietary reference intakes were computed for all subjects (National Academy of Sciences, National Research Council, Food \& Nutrition Board, 1989; Committee on Dietary Allowances, Food \& Nutrition Board, National Research Council, 2001). The $\chi^{2}$ test was used to examine the differences within the percentage of the two groups not meeting the two-thirds of RDA. Justification of the chosen two-thirds RDA cut off is based on the fact that RDA are designed to meet the needs of practically all healthy individuals 
and include a substantial margin of safety (Food \& Nutrition Board, 1985).

Pre-holy days values comprise the mean of the three measurements that were made before the beginning of the Christmas, Lent and Assumption fasting periods, while end-holy days values are the mean of the three measurements that were made at the end of each one of the fasting periods.

\section{Results}

Demographic data of the study population are presented in Table 1 . There were no statistically significant differences in sex, age, and educational level of the two groups. Fasters had been practising the fasting rituals for a mean of 20 (SD 14) years and they consisted of twenty laypersons (fasted for 13 (SD 10) years), nineteen nuns living in convents (fasted for 24 (SD 16) years) and twenty-one priests living with their families in community parishes (fasted for 21 (SD 13) years).

\section{Validity of the $24 \mathrm{~h}$ recall method}

The number of the $24 \mathrm{~h}$ recalls that were gathered in each of the six measurements ranged from 43 to 60 while the $3 \mathrm{~d}$ weighed food records that were returned ranged from 19 to 48. Only $30 \%$ of the subjects returned all six $3 \mathrm{~d}$ weighed food records and $7 \%$ returned none; $40 \%$ of fasters and $20 \%$ of controls returned all six $3 \mathrm{~d}$ food records (group A) $\left(P<0.05 ; \chi^{2}\right.$ test $)$ as compared with those who returned none or up to five food records (group B). In comparison with group B, group A's fasters had lower levels of preand end-total serum cholesterol $(P<0.05$ and $P<0.01$ respectively; Mann-Whitney test) and pre- and endLDL-cholesterol $(P<0.05$ and $P<0.01$ respectively; Mann-Whitney test). Group A's controls had lower levels of pre- and end-BMI $(P<0.05$; Mann-Whitney test). Therefore, it was decided to use only the $24 \mathrm{~h}$ dietary recall records for the analyses of foods and nutrients.

The validity of the $24 \mathrm{~h}$ dietary recall was studied by comparing it with the $3 \mathrm{~d}$ weighed food record. The paired samples $t$ test was carried out to evaluate the significance

Table 1. Socio-demographic characteristics of the population

\begin{tabular}{|c|c|c|c|}
\hline & $\begin{array}{c}\text { Fasters } \\
n \%\end{array}$ & $\begin{array}{c}\text { Controls } \\
n \%\end{array}$ & $P$ \\
\hline \multicolumn{4}{|l|}{ Sex } \\
\hline Males & 3152 & 2440 & $\mathrm{NS}^{*}$ \\
\hline Females & 2948 & 3660 & \\
\hline Age (years):Mean & 42 & 38 & NS† \\
\hline SD & 12 & 9 & \\
\hline \multicolumn{4}{|l|}{ Tobacco use } \\
\hline Smokers & 47 & 3355 & $<0.001^{*}$ \\
\hline Non-smokers & 5693 & 2745 & \\
\hline \multicolumn{4}{|l|}{ Educational level } \\
\hline Higher & 2643 & 1423 & $N S^{*}$ \\
\hline Secondary & 2440 & 3457 & \\
\hline $\begin{array}{l}\text { Minimum school level or no } \\
\text { education }\end{array}$ & 1017 & 1220 & \\
\hline
\end{tabular}

${ }^{*} \chi^{2}$ test-Fisher exact test.

+ ANOVA analysis. of the difference between the two dietary methods in fasters and controls separately (data not shown). The differences in mean nutrient intake were 8.7 (95\% CI 6.8, 10.8) \% and $9.4(95 \%$ CI $7.0,11.9) \%$ for control subjects and fasters respectively (data not shown). This mean difference of less than $10 \%$ indicates a good agreement between measures (Sharma et al. 1998; Marjan et al. 1999). The $24 \mathrm{~h}$ dietary recall has been previously validated in relation to fat intake based on measurements with adipose tissue aspiration and fatty acid composition analysis (Kafatos et al. 1991; Knutsen et al. 2003); and in placing individuals in the distribution of habitual diet (Bingham et al. 1997).

\section{Comparisons of nutrient intakes}

Table 2 presents the mean intakes of energy, selected micronutrients and macronutrients during pre- and endholy days measurements in each fasting period under study and compares the changes that were observed in fasters with the changes observed in the controls. Compared with the control subjects, fasters presented significantly greater mean changes in energy intake at Christmas and the Assumption. Dietary cholesterol, total fat (\% energy), saturated fatty acids (SFA; \% energy), protein (\% energy), and $\mathrm{Ca}$ levels were also decreased in fasters in all three end-holy periods, though the values for protein and total fat did not reach statistical significance during Christmas and Lent respectively. In addition, fibre (g) and carbohydrates (\% energy) were generally increased though not always significantly.

Comparisons of the mean changes of energy and nutrient intakes in the three pre-holy and the three end-holy periods are shown in Table 3. Compared with controls, fasters presented reduced energy intake at end-holy periods $(P<0.05)$. The contribution of end-holy days protein, total fat, SFA and trans-fatty acids to energy intake were reduced to $10,31.6,5.6$ and $0.12 \%$ in fasters, while the respective values for the controls were 14.4, 39.1, 11.4 and $0.58 \%(P<0.001)$. The controls' intake of PUFA $(\mathrm{g})$ was higher compared with that of fasters $(P<0.05)$, but this was not sustained when PUFA was compared as percentage of energy. End-holy days dietary cholesterol (per $4.184 \mathrm{MJ}$; per $1000 \mathrm{kcal}$ ) was reduced by $108.5 \mathrm{mg}$ in fasters and increased by $3 \cdot 1$ in controls $(P<0 \cdot 001)$. Vitamins $\mathrm{A}, \mathrm{C}, \mathrm{E}, \mathrm{B}_{1}, \mathrm{~B}_{6}, \mathrm{~B}_{12}$ and niacin did not differ between the two groups. Fasters also had higher intakes of end-holy days fibre, folate and Fe per $4 \cdot 184 \mathrm{MJ}$ (per $1000 \mathrm{kcal}$ ) $(P<0.001, P<0.05$ and $P<0.001$ respectively) and lower end-holy days $\mathrm{Ca}$ intakes $(P<0 \cdot 001)$.

Table 4 presents the percentages of fasters and controls that were below the two-thirds $(67 \%)$ of RDA in eleven nutrients. No differences were observed with the exception of $\mathrm{Ca}$ and protein where more fasters were $<67 \%$ of RDA.

\section{Comparisons of food consumption}

Mean quantities of the consumed foods derived from the $24 \mathrm{~h}$ dietary recall during the pre- and end-holy periods in both groups are presented in Table 5. Fasters and controls had no significant differences in either their pre- or end-holy 
K. O. Sarri et al.

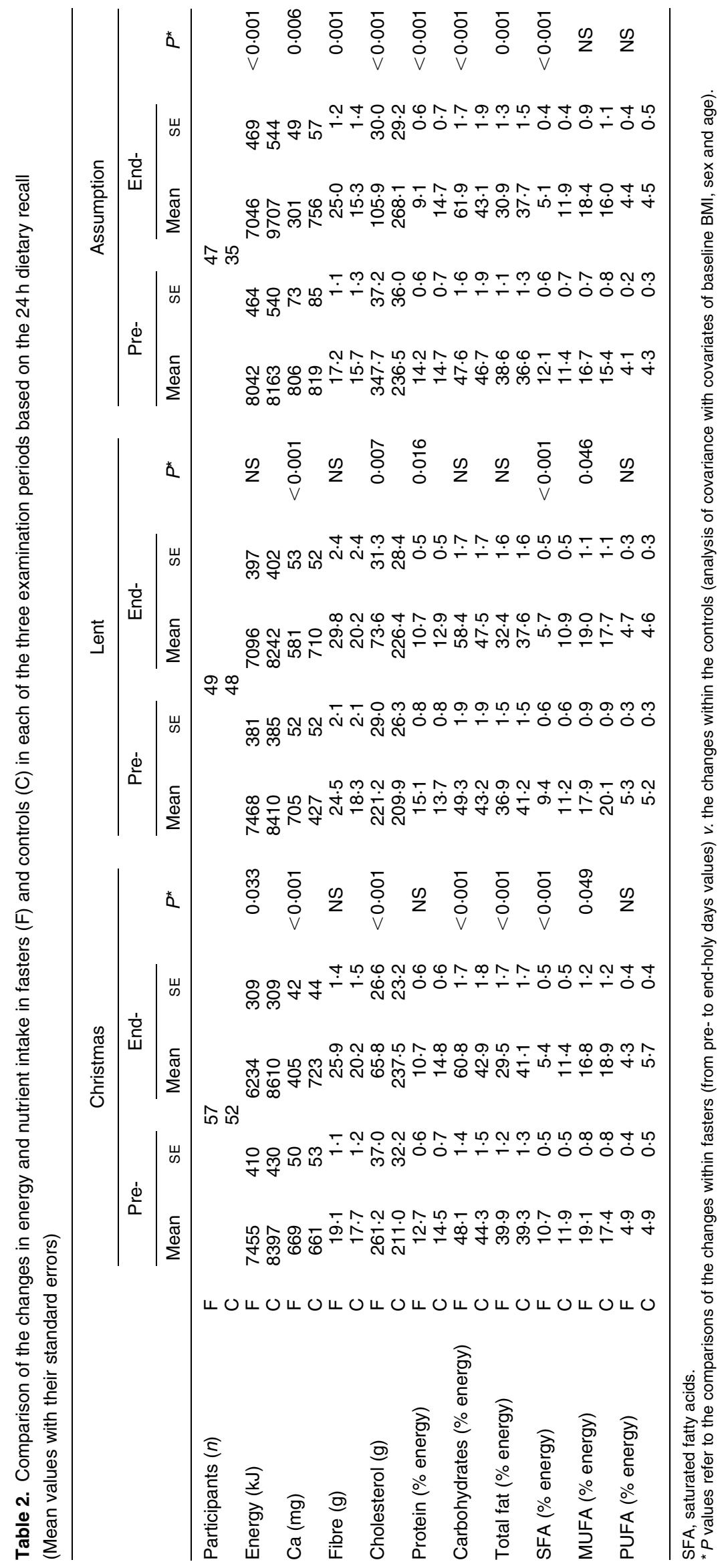


Table 3. Comparison of the changes between pre- and end-holy periods in nutrient and energy intake in fasters $(F ; n 59)$ and controls ( $;$; $n$ 56) based on the $24 \mathrm{~h}$ dietary recall

(Mean values with their standard errors)

\begin{tabular}{|c|c|c|c|c|c|c|c|c|}
\hline & & \multicolumn{2}{|c|}{ Pre- } & \multicolumn{2}{|c|}{ End- } & \multicolumn{2}{|c|}{ Changes } & \multirow[b]{2}{*}{$P^{\star}$} \\
\hline & & Mean & SE & Mean & SE & Mean & SE & \\
\hline \multirow[t]{2}{*}{ Energy (kJ) } & $\mathrm{F}$ & 7427 & 305 & 6673 & 264 & -753 & 280 & 0.002 \\
\hline & C & 7950 & 314 & 8523 & 272 & 573 & 289 & \\
\hline \multirow[t]{2}{*}{ Protein (\% energy) } & $\mathrm{F}$ & 13.9 & 0.4 & $10 \cdot 0$ & 0.4 & -3.9 & 0.6 & $<0.001$ \\
\hline & C & 14.3 & 0.5 & 14.4 & 0.4 & 0.2 & 0.6 & \\
\hline \multirow[t]{2}{*}{ Carbohydrates (\% energy) } & $\mathrm{F}$ & $48 \cdot 7$ & $1 \cdot 1$ & 59.9 & $1 \cdot 2$ & $11 \cdot 3$ & 1.3 & $<0.001$ \\
\hline & C & 45.5 & $1 \cdot 1$ & 44.6 & 1.3 & -0.9 & 1.3 & \\
\hline \multirow[t]{2}{*}{ Total fat (\% energy) } & $\mathrm{F}$ & 38.4 & 0.8 & 31.6 & 1.1 & -6.9 & 1.1 & $<0.001$ \\
\hline & C & 38.7 & 0.8 & $39 \cdot 1$ & $1 \cdot 1$ & 0.4 & 1.1 & \\
\hline \multirow[t]{2}{*}{ SFA (\% energy) } & $\mathrm{F}$ & $10 \cdot 6$ & 0.4 & $5 \cdot 6$ & 0.3 & -4.9 & 0.4 & $<0.001$ \\
\hline & C & 11.4 & 0.4 & 11.4 & 0.3 & 0.1 & 0.4 & \\
\hline \multirow[t]{2}{*}{ MUFA (\% energy) } & $\mathrm{F}$ & $18 \cdot 1$ & 0.4 & $18 \cdot 4$ & 0.7 & 0.3 & 0.7 & NS \\
\hline & C & $17 \cdot 6$ & 0.5 & $17 \cdot 7$ & 0.8 & 0.1 & 0.7 & \\
\hline \multirow[t]{2}{*}{ PUFA (\% energy) } & $\mathrm{F}$ & 4.8 & 0.2 & 4.5 & 0.2 & -0.3 & 0.3 & NS \\
\hline & C & 4.8 & 0.2 & $5 \cdot 1$ & 0.2 & 0.2 & 0.3 & \\
\hline \multirow{2}{*}{ Trans-fatty acids (\% energy) } & $\mathrm{F}$ & 0.56 & 0.04 & 0.12 & 0.03 & -0.43 & 0.05 & $<0.001$ \\
\hline & C & 0.59 & 0.05 & 0.58 & 0.03 & -0.01 & 0.05 & \\
\hline \multirow[t]{2}{*}{$n-6: n-3$ Ratio } & $\mathrm{F}$ & 12.5 & 0.5 & 11.5 & 0.6 & -1.1 & 0.8 & 0.015 \\
\hline & C & 11.5 & 0.5 & 13.0 & 0.6 & 1.5 & 0.8 & \\
\hline \multirow[t]{2}{*}{ Alcohol† (g) } & $\mathrm{F}$ & $12 \cdot 6$ & $8 \cdot 7$ & $17 \cdot 2$ & $7 \cdot 8$ & $4 \cdot 6$ & $6 \cdot 3$ & NS \\
\hline & C & 52 & $9 \cdot 2$ & $47 \cdot 3$ & $8 \cdot 3$ & $-4 \cdot 6$ & $6 \cdot 8$ & \\
\hline \multirow[t]{2}{*}{ Fibre (per 4.184 MJ) } & $\mathrm{F}$ & 11.9 & 0.5 & $16 \cdot 9$ & 0.5 & $5 \cdot 1$ & 0.6 & $<0.001$ \\
\hline & C & 9.3 & 0.5 & $9 \cdot 6$ & 0.5 & 0.3 & 0.7 & \\
\hline \multirow[t]{2}{*}{ Vitamin $A \ddagger(\mu \mathrm{g})$} & $\mathrm{F}$ & 888 & 74 & 940 & 121 & 51 & 125 & NS \\
\hline & C & 753 & 76 & 871 & 124 & 119 & 129 & \\
\hline \multirow[t]{2}{*}{ Vitamin E‡ (mg) } & $\mathrm{F}$ & 8.7 & 0.5 & 9.3 & 1.1 & 0.6 & 1.2 & NS \\
\hline & C & 8.4 & 0.5 & 10.7 & $1 \cdot 1$ & $2 \cdot 4$ & 1.2 & \\
\hline \multirow[t]{2}{*}{ Vitamin C $\ddagger$ (mg) } & $\mathrm{F}$ & 133.4 & $8 \cdot 1$ & $166 \cdot 2$ & $9 \cdot 7$ & $32 \cdot 8$ & $9 \cdot 8$ & NS \\
\hline & C & $112 \cdot 7$ & $8 \cdot 3$ & $130 \cdot 1$ & 9.9 & 17.4 & $10 \cdot 1$ & \\
\hline \multirow{2}{*}{ Vitamin $B_{1} \ddagger(m g)$} & $\mathrm{F}$ & 1.45 & 0.10 & 1.56 & 0.11 & 0.12 & 0.14 & NS \\
\hline & C & 1.91 & 0.10 & 1.99 & 0.11 & 0.07 & 0.14 & \\
\hline \multirow[t]{2}{*}{ Vitamin $B_{2} \ddagger(\mathrm{mg})$} & $\mathrm{F}$ & 1.54 & 0.08 & 1.07 & 0.06 & -0.46 & 0.08 & $<0.001$ \\
\hline & C & 1.54 & 0.09 & 1.64 & 0.06 & 0.08 & 0.09 & \\
\hline \multirow[t]{2}{*}{ Niacinł (mg) } & $\mathrm{F}$ & $15 \cdot 2$ & $0 \cdot 8$ & $13 \cdot 6$ & 0.7 & $-1 \cdot 6$ & 0.9 & NS \\
\hline & C & $17 \cdot 8$ & 0.8 & $18 \cdot 6$ & 0.7 & 0.8 & 0.9 & \\
\hline Vitamin $B_{6} \ddagger(\mathrm{mg})$ & $\mathrm{F}$ & 1.48 & 0.08 & 1.39 & 0.07 & -0.09 & 0.09 & NS \\
\hline & C & 1.61 & 0.08 & 1.64 & 0.07 & 0.03 & 0.09 & \\
\hline Vitamin $B_{12} \ddagger(\mu \mathrm{g})$ & $\mathrm{F}$ & 2.99 & 0.49 & 1.48 & 0.35 & -1.48 & $0 \cdot 6$ & NS \\
\hline & C & 3.92 & 0.49 & 2.95 & 0.36 & -0.96 & 0.6 & \\
\hline Cholesterol (per 4.184 MJ) & $\mathrm{F}$ & $150 \cdot 9$ & $11 \cdot 1$ & $42 \cdot 6$ & $6 \cdot 3$ & -108.5 & $12 \cdot 9$ & $<0.001$ \\
\hline & C & $108 \cdot 8$ & 11.4 & 111.9 & $6 \cdot 4$ & $3 \cdot 1$ & $13 \cdot 2$ & \\
\hline Ca (per 4.184 MJ) & $\mathrm{F}$ & $391 \cdot 1$ & $21 \cdot 1$ & $257 \cdot 2$ & $16 \cdot 9$ & $-133 \cdot 1$ & $24 \cdot 0$ & 0.001 \\
\hline & $\mathrm{C}$ & 397.4 & $21 \cdot 7$ & $386 \cdot 2$ & $17 \cdot 4$ & $-11 \cdot 2$ & $24 \cdot 1$ & \\
\hline $\mathrm{Fe}($ per $4.184 \mathrm{MJ})$ & $\mathrm{F}$ & 6.4 & 0.2 & 8.5 & 0.2 & $2 \cdot 1$ & 0.3 & $<0.001$ \\
\hline & C & $6 \cdot 3$ & 0.2 & $6 \cdot 2$ & 0.2 & -0.1 & 0.3 & \\
\hline Folate (per 4.184 MJ) & $\mathrm{F}$ & $142 \cdot 7$ & $8 \cdot 3$ & $198 \cdot 6$ & $10 \cdot 3$ & $56 \cdot 9$ & $13 \cdot 4$ & 0.009 \\
\hline & $\mathrm{C}$ & $113 \cdot 5$ & $8 \cdot 6$ & $116 \cdot 9$ & $10 \cdot 6$ & $3 \cdot 3$ & $13 \cdot 8$ & \\
\hline
\end{tabular}

SFA, saturated fatty acids.

${ }^{*}$ Analysis of covariance with covariates of age, sex and baseline BMI.

†Only drinkers were included (eighteen fasters, sixteen controls; Mann-Whitney test).

$\ddagger$ Values per 4.184 MJ are not included since they were found to be NS.

days consumption of bread, cereals and sugar products. Fasters do not consume eggs, meat, cheese, milk and yoghurt in end-holy periods since it is not allowed according to the Orthodox Christian practices, and so no comparison could be made regarding these food categories. Fasters consumed significantly more pulses and eggs in the preholy period in comparison with controls $(P<0.05)$, and a significantly higher consumption of potatoes and of fruit and vegetables at the end-holy periods in comparison with controls $(P<0.05$ and $P<0.001$ respectively). Compared with fasters, controls consumed more alcohol in all periods $(P<0.05)$.

\section{Discussion}

The main finding of the present study is that faithful adherents of Christian Orthodox Church dietary recommendations present a more beneficial dietary profile regarding nutrient intake and food consumption, with the exception of $\mathrm{Ca}$ intake. Religious fasting decreased energy intake, dietary cholesterol and the percentages of dietary protein, total fat, SFA and trans-fatty acids, while, on the other hand, it increased the percentage of total carbohydrates along with the intakes of fibre, folate and Fe. 
Table 4. Fasters and controls in the pre- and end-holy periods with nutrient intake $<67 \%$ recommended dietary allowances

\begin{tabular}{|c|c|c|c|c|c|c|}
\hline & & \multicolumn{2}{|c|}{ Fasters } & \multicolumn{2}{|c|}{ Controls } & \multirow[b]{2}{*}{$P^{\star}$} \\
\hline & & $n$ & $\%$ & $n$ & $\%$ & \\
\hline \multirow[t]{2}{*}{ Energy } & Pre- & 25 & 43 & 24 & 42 & NS \\
\hline & End- & 30 & 51 & 14 & 25 & \\
\hline \multirow[t]{2}{*}{$\mathrm{Ca}$} & Pre- & 19 & 33 & 21 & 37 & 0.004 \\
\hline & End- & 51 & 86 & 17 & 30 & \\
\hline \multirow[t]{2}{*}{$\mathrm{Fe}$} & Pre- & 11 & 18 & 15 & 27 & NS \\
\hline & End- & 4 & 7 & 13 & 23 & \\
\hline \multirow[t]{2}{*}{ Folate } & Pre- & 8 & 13 & 11 & 20 & NS \\
\hline & End- & 3 & 5 & 11 & 20 & \\
\hline \multirow[t]{2}{*}{ Vitamin A } & Pre- & 25 & 43 & 29 & 52 & NS \\
\hline & End- & 34 & 58 & 30 & 54 & \\
\hline \multirow[t]{2}{*}{ Vitamin C } & Pre- & 1 & 2 & 8 & 15 & NS \\
\hline & End- & 1 & 2 & 5 & 9 & \\
\hline \multirow[t]{2}{*}{ Vitamin E } & Pre- & 13 & 22 & 17 & 30 & NS \\
\hline & End- & 10 & 17 & 13 & 23 & \\
\hline \multirow[t]{2}{*}{ Mg } & Pre- & 19 & 33 & 13 & 23 & NS \\
\hline & End- & 14 & 24 & 8 & 14 & \\
\hline \multirow[t]{2}{*}{$P$} & Pre- & 8 & 13 & 4 & 8 & NS \\
\hline & End- & 52 & 88 & 55 & 98 & \\
\hline \multirow[t]{2}{*}{ Protein } & Pre- & 9 & 15 & 7 & 12 & 0.006 \\
\hline & End- & 33 & 56 & 3 & 5 & \\
\hline \multirow[t]{2}{*}{ Vitamin $B_{12}$} & Pre- & 16 & 27 & 10 & 18 & NS \\
\hline & End- & 40 & 68 & 10 & 18 & \\
\hline
\end{tabular}

${ }^{*} \chi^{2}$ test-Fisher exact test.
The changes observed in fasters' nutrient intakes could be explained by their significantly increased consumption of fruit, vegetable and pulses (Moschandreas \& Kafatos, 1999), potatoes and cereals (Robinson et al. 2002), and by their abstinence from meat, dairy products and eggs during the fasting periods.

The reduction in end-fasting $\mathrm{Ca}$ intake is also attributed to the fasters' restricted diet. However, short-term inadequacy in $\mathrm{Ca}$ intake is not detrimental to health (O'Brien et al. 1996).

Furthermore, we assume that the increase in Fe intakes refers to non-haem $\mathrm{Fe}$ since fasters abstained from all haem-Fe sources and consumed more food containing non-haem Fe. Nevertheless, this finding is not surprising since studies in vegetarians, whose dietary habits are similar to the Orthodox Christian fasting principles, have shown that their $\mathrm{Fe}$ intakes are similar to those of omnivores (Thane \& Bates, 2000; Larsson \& Johansson, 2002).

The present findings support the significant reductions in serum lipids and obesity indices that Greek Orthodox fasters presented at the completion of the fasting periods that have been recently published by Sarri et al. (2003). Greek Orthodox fasters had decreased levels of end-fasting total cholesterol, LDL-cholesterol, triacylglycerols, LDL:HDL cholesterol ratio and BMI; although these reductions were not maintained until the next fasting

Table 5. Comparison of selected foods intake $(\mathrm{g} / \mathrm{d})$ in fasters and controls based on the $24 \mathrm{~h}$ dietary recall at pre-holy periods

(Mean values and standard deviations)

\begin{tabular}{|c|c|c|c|c|c|c|c|c|}
\hline & & \multicolumn{3}{|c|}{ Fasters } & \multicolumn{3}{|c|}{ Controls } & \multirow[b]{2}{*}{$P^{\star}$} \\
\hline & & Mean & SD & $n$ & Mean & SD & $n$ & \\
\hline \multirow[t]{2}{*}{ Bread } & Pre- & 104 & 52 & 60 & 115 & 77 & 58 & NS \\
\hline & End- & 107 & 38 & 59 & 126 & 59 & 56 & NS \\
\hline \multirow[t]{2}{*}{ Cereals } & Pre- & 195 & 135 & 42 & 159 & 130 & 45 & NS \\
\hline & End- & 227 & 167 & 47 & 206 & 159 & 41 & NS \\
\hline \multirow[t]{2}{*}{ Potatoes } & Pre- & 181 & 86 & 41 & 172 & 98 & 41 & NS \\
\hline & End- & 218 & 133 & 51 & 159 & 94 & 45 & 0.016 \\
\hline \multirow[t]{2}{*}{ Milk and yoghurt } & Pre- & 164 & 131 & 42 & 152 & 156 & 45 & NS \\
\hline & End- & 0 & 0 & & 153 & 145 & 42 & - \\
\hline \multirow[t]{2}{*}{ Eggs } & Pre- & 93 & 49 & 32 & 59 & 39 & 25 & 0.010 \\
\hline & End- & 0 & 0 & & 64 & 54 & 23 & - \\
\hline \multirow[t]{2}{*}{ Cheese } & Pre- & 53 & 27 & 46 & 53 & 36 & 47 & NS \\
\hline & End- & 0 & 0 & & 52 & 33 & 49 & - \\
\hline \multirow[t]{2}{*}{ Meat } & Pre- & 145 & 87 & 32 & 145 & 91 & 54 & NS \\
\hline & End- & 0 & 0 & & 163 & 96 & 51 & - \\
\hline \multirow[t]{2}{*}{ Fish and shellfish } & Pre- & 106 & 91 & 33 & 144 & 79 & 27 & 0.029 \\
\hline & End- & 114 & 71 & 30 & 117 & 100 & 25 & NS \\
\hline \multirow[t]{2}{*}{ Pulses } & Pre- & 416 & 142 & 21 & 272 & 139 & 21 & 0.029 \\
\hline & End- & 347 & 142 & 36 & 355 & 214 & 21 & NS \\
\hline \multirow[t]{2}{*}{ Fruit and vegetables } & Pre- & 471 & 201 & 60 & 408 & 255 & 58 & NS \\
\hline & End- & 502 & 198 & 59 & 364 & 210 & 56 & $<0.001$ \\
\hline \multirow[t]{2}{*}{ Alcohol } & Pre- & 170 & 162 & 22 & 302 & 265 & 32 & 0.039 \\
\hline & End- & 136 & 101 & 25 & 297 & 232 & 21 & 0.004 \\
\hline \multirow[t]{2}{*}{ Fats and oils } & Pre- & 30 & 16 & 56 & 24 & 14 & 55 & 0.024 \\
\hline & End- & 29 & 19 & 59 & 24 & 12 & 54 & NS \\
\hline \multirow[t]{2}{*}{ Sugar products } & Pre- & 13 & 9 & 54 & 18 & 18 & 52 & NS \\
\hline & End- & 17 & 20 & 53 & 17 & 10 & 47 & NS \\
\hline \multirow[t]{2}{*}{ Pastries } & Pre- & 75 & 17 & 38 & 75 & 59 & 39 & NS \\
\hline & End- & 56 & 33 & 30 & 110 & 101 & 34 & 0.009 \\
\hline
\end{tabular}

* Mann-Whitney test. 
period, the values of total cholesterol and LDL-cholesterol never reached the initial pre-holy days levels (Sarri et al. 2003).

The findings on the composition of the fasters' diet and their dietary patterns are in agreement with those of Kafatos et al. (2000) who also investigated a small sample of Orthodox Christian fasters. Contrary to the present findings, the diet of the Orthodox Christian Church met $100 \%$ of RDA for every nutrient, except for Ca (Kafatos et al. 2000). However, in the present study the two groups had similar percentages below two-thirds of the RDA.

The levels of the $n-6: n-3$ ratio presented in the present study are high for both groups, as compared with the traditional diet of Crete before 1960 which was characterised by a balanced $n-6: n-3$ ratio ranging from $1: 1$ to $2: 1$ (Simopoulos, 2001). However, in comparison with preholy days, fasters decreased their end-holy days ratio by $9 \%$ while controls increased it by $13 \%$. Additionally, fasters' end-holy days $n$ - 3 fatty acids consisted of $10 \%$ more $\alpha$-linolenic acid, while the respective increase for the controls in $\alpha$-linolenic acid was $2 \%$ (data not shown). A high $n-6: n-3$ fatty acids ratio has been associated with chronic diseases (Simopoulos, 2002).

Limited studies have looked into the association of different religions such as Judaism and the Muslim faith with the adoption of healthier dietary habits. Secular Jewish who had higher levels of plasma lipids were also found to consume more total fat, more SFA and fewer carbohydrates than religious subjects (Friedlander et al. 1985). Additionally, $\mathrm{Ca}$ and $\mathrm{P}$ intakes in orthodox Jews were below adequate intake due to the limited consumption of dairy products (Taha et al. 2001). Insufficient Ca intake was also found in Muslims during the month of Ramadan (Karaagaoglu \& Yucecan, 2000). The studies on Ramadan fasting and its effect on plasma lipids and lipoproteins are not consistent. Some highlight its beneficial effects on lowering total cholesterol, triacylglycerols and increasing HDL-cholesterol (Adlouni et al. 1997), while others show no significant changes on plasma lipids (Maislos et al. 1993, 1998; Temizhan et al. 2000). Additionally, either no (el Ati et al. 1995; Finch et al. 1998) or a small effect (Adlouni et al. 1998) on body weight has been observed. Ramadan is characterised by a higher total energy, protein and carbohydrate intake (Frost \& Pirani, 1987; Adlouni et al. 1997). However, the findings regarding total fat intake are contradicting (Frost \& Pirani, 1987; Adlouni et al. 1997, 1998). Last, during Ramadan the secular are involved in more stress-reducing and spiritual activities, they smoke less, drink less caffeine and eat higher proportions from all food groups (Afifi, 1997).

The impact of religious beliefs on adopting a healthier lifestyle, especially regarding their hygiene, nutrition, physical activity and psychological status has also been shown in Greek Orthodox Christians (Chliaoutakis et al. 2002). Chliaoutakis et al. (2002) pointed out that one out of three individuals in Greece adopts the lifestyle that the Greek Orthodox Church suggests and that Orthodox Christianity has a strong impact on the Greeks' dietary behaviour.

Another religious group, Seventh-Day Adventists, is a well-studied group for its health-promoting lifestyle.
Devout Seventh-Day Adventists are non-smokers, they drink little alcohol and coffee and they mostly practise a lacto-ovo-vegetarian diet. Vegetarian Adventist adherents live longer than their non-vegetarian Adventist counterparts (Fraser, 1999a). In addition, they have significantly lower blood glucose, lipid levels and body weight and consequently present with fewer CVD risk factors (Nieman et al. 1989; Famodu et al. 1998; Fraser 1999b).

There are several limitations in the present study. A power calculation was not used in determining sample sizes because of the lack of any previous similar study and because no pilot study was preceded. We were limited in our assessment of nutrient intake due to the large proportion of unreturned $3 \mathrm{~d}$ weighed food records. The $24 \mathrm{~h}$ dietary recalls can mostly give an estimate of the average nutrient intake, especially regarding micronutrients, and that possibly explains the differences found in micronutrient intakes when we compared the two dietary assessment methods. On the other hand, macronutrients performed well. In addition, we cannot rule out the possibility of some bias since all our subjects were volunteers. However, the design of the present study was very demanding as regards the dietary inclusion criteria. Therefore, more attention was paid in matching the subjects in this context, than in other factors such as smoking.

The present study is one of the first studies that attempt to present an overall picture of the Mediterranean type of diet that is recommended by the Greek Orthodox Church. The Christian Orthodox diet is an important characteristic of the Mediterranean diet of Crete, which contributes greatly to the good health and nutritional status of the population (Sarri et al. 2003).

\section{References}

Adlouni A, Ghalim N, Benslimane A, Lecerf JM \& Saile R (1997) Fasting during Ramadan induces a marked increase in high-density lipoprotein cholesterol and decrease in low-density lipoprotein cholesterol. Ann Nutr Metab 41, 242-249.

Adlouni A, Ghalim N, Saile R, Hda N, Parra HJ \& Benslimane A (1998) Beneficial effect on serum apo AI, apo B and Lp AI levels of Ramadan fasting. Clin Chim Acta 271, 179-189.

Afifi ZE (1997) Daily practices, study performance and health during the Ramadan fast. $J$ R Soc Health 117, 231-235.

Berrino F \& Muti P (1989) Mediterranean diet and cancer. Eur J Clin Nutr 43, 49-55.

Bingham SA, Gill C, Welch A, et al. (1997) Validation of dietary assessment methods in the UK arm of EPIC using weighed records, and 24-hour urinary nitrogen and potassium and serum vitamin $\mathrm{C}$ and carotenoids as biomarkers. Int J Epidemiol 26, S137-S151.

Chliaoutakis JE, Darviri C \& Demakakos PT (1999) The impact of young drivers lifestyle on their road traffic accident risk in greater Athens area. Accid Anal Prev 31, 771-780.

Chliaoutakis JE, Drakou I, Gnardellis C, Galariotou S, Carra H \& Chliaoutaki M (2002) Greek christian orthodox ecclesiastical lifestyle: could it become a pattern of health-related behavior? Prev Med 34, 428-435.

Committee on Dietary Allowances, Food and Nutrition Board, National Research Council (2001) Dietary Reference Intakes for Calcium, Phosphorus, Magnesium, Vitamin D, and Fluoride. Washington, DC: National Academy Press. 
el Ati J, Beji C \& Danguir J (1995) Increased fat oxidation during Ramadan fasting in healthy women: an adaptative mechanism for body-weight maintenance. Am J Clin Nutr 62, 302-307.

Famodu AA, Osilesi O, Makinde YO \& Osonuga OA (1998) Blood pressure and blood lipid levels among vegetarian, semi-vegetarian, and non-vegetarian native Africans. Clin Biochem 31, 545-549.

Ferro-Luzzi A, James WP \& Kafatos A (2002) The high-fat Greek diet: a recipe for all? Eur J Clin Nutr 56, 796-809.

Finch GM, Day JE, Razak Welch DA \& Rogers PJ (1998) Appetite changes under free-living conditions during Ramadan fasting. Appetite 31, 159-170.

Food and Nutrition Board (1985) Recommended Dietary Allowances. Washington, DC: National Academy Press.

Fraser GE (1999a) Associations between diet and cancer, ischemic heart disease, and all-cause mortality in non-Hispanic white California Seventh-day Adventists. Am J Clin Nutr 70, 532S-538S.

Fraser GE (1999b) Diet as primordial prevention in Seventh-Day Adventists. Prev Med 29, S18-S23.

Friedlander Y, Kark JD, Kaufmann NA \& Stein Y (1985) Coronary heart disease risk factors among religious groupings in a Jewish population sample in Jerusalem. Am J Clin Nutr 42, 511-521.

Frost G \& Pirani S (1987) Meal frequency and nutritional intake during Ramadan: a pilot study. Hum Nutr Appl Nutr 41, 47-50.

James WP, Duthie GG \& Wahle KW (1989) The Mediterranean diet: protective or simply non-toxic? Eur J Clin Nutr 43, 31-41.

Kafatos A, Kouroumalis I, Vlachonikolis I, Theodorou C \& Labadarios D (1991) Coronary-heart-disease risk-factor status of the Cretan urban population in the 1980s. Am J Clin Nutr 54, 591-598.

Kafatos A \& Mamalakis G (1993) Changing patterns of fat intake in Crete. Eur J Clin Nutr 47, Suppl. 1, S21-S24.

Kafatos A, Verhagen H, Moschandreas J, Apostolaki I \& van Westerop JJ (2000) Mediterranean diet of Crete: foods and nutrient content. $J$ Am Diet Assoc 100, 1487-1493.

Karaagaoglu N \& Yucecan S (2000) Some behavioural changes observed among fasting subjects, their nutritional habits and energy expenditure in Ramadan. Int J Food Sci Nutr 51, $125-134$

Keys A (1980) Wine, garlic, and CHD in seven countries. Lancet i, $145-146$.

Keys A, Menotti A, Karvonen MJ, et al. (1986) The diet and 15year death rate in the seven countries study. Am J Epidemiol 124, 903-915.

Knutsen SF, Fraser GE, Beeson WL, Lindsted KD \& Shavlik DJ (2003) Comparison of adipose tissue fatty acids with dietary fatty acids as measured by 24-hour recall and food frequency questionnaire in Black and White Adventists: the Adventist Health Study. Ann Epidemiol 13, 119-127.

Kromhout D, Keys A, Aravanis C, et al. (1989) Food consumption patterns in the 1960s in seven countries. Am J Clin Nutr 49, 889-894.

Larsson CL \& Johansson GK (2002) Dietary intake and nutritional status of young vegans and omnivores in Sweden. Am J Clin Nutr 76, 100-106.

Maislos M, Abou-Rabiah Y, Zuili I, Iordash S \& Shany S (1998) Gorging and plasma HDL-cholesterol - the Ramadan model. Eur J Clin Nutr 52, 127-130.

Maislos M, Khamaysi N, Assali A, Abou-Rabiah Y, Zvili I \& Shany S (1993) Marked increase in plasma high-density-lipoprotein cholesterol after prolonged fasting during Ramadan. Am J Clin Nutr 57, 640-642.

Marjan ZM, Badari SAZ \& Kandiah M (1999) Assessment of dietary intake among university students: 24-hour recall verses weighed record method. Mal J Nutr 5, 15-20.

Menotti A, Kromhout D, Blackburn H, Fidanza F, Buzina R \& Nissinen A (1999) Food intake patterns and 25-year mortality from coronary heart disease: cross-cultural correlations in the Seven Countries Study. The Seven Countries Study Research Group. Eur J Epidemiol 15, 507-515.

Moschandreas J \& Kafatos A (1999) Food and nutrient intakes of Greek (Cretan) adults. Recent data for food-based dietary guidelines in Greece. Br J Nutr 81, Suppl. 2, S71-S76.

National Academy of Sciences, National Research Council, Food and Nutrition Board (1989) Recommended Dietary Allowances, 10th ed. Washington, DC: National Academy Press.

Nieman DC, Underwood BC, Sherman KM, Arabatzis K, Barbosa JC, Johnson M \& Shultz TD (1989) Dietary status of SeventhDay Adventist vegetarian and non-vegetarian elderly women. $J$ Am Diet Assoc 89, 1763-1769.

O'Brien KO, Abrams SA, Liang LK, Ellis KJ \& Gagel RF (1996) Increased efficiency of calcium absorption during short periods of inadequate calcium intake in girls. Am J Clin Nutr 63, $579-583$.

Robinson F, Hackett AF, Billington D \& Stratton G (2002) Changing from a mixed to self-selected vegetarian diet - influence on blood lipids. J Hum Nutr Diet 15, 323-329.

Sarri KO, Tzanakis NE, Linardakis MK, Mamalakis GD \& Kafatos AG (2003) Effects of Greek orthodox christian church fasting on serum lipids and obesity. BMC Public Health 3, 16.

Sharma M, Rao M, Jacob S \& Jacob CK (1998) Validation of 24hour dietary recall: a study in hemodialysis patients. J Ren Nutr 8, 199-202.

Simopoulos AP (2001) The Mediterranean diets: what is so special about the diet of Greece? The scientific evidence. Nutr 131, 3065S-3073S.

Simopoulos AP (2002) The importance of the ratio of omega-6/ omega-3 essential fatty acids. Biomed Pharmacother 56, $365-379$.

Taha W, Chin D, Silverberg AI, Lashiker L, Khateeb N \& Anhalt $\mathrm{H}$ (2001) Reduced spinal bone mineral density in adolescents of an Ultra-Orthodox Jewish community in Brooklyn. Pediatrics 107, E79.

Temizhan A, Tandogan I, Donderici O \& Demirbas B (2000) The effects of Ramadan fasting on blood lipid levels. Am J Med 109, $341-342$.

Thane CW \& Bates CJ (2000) Dietary intakes and nutrient status of vegetarian preschool children from a British national survey. J Hum Nutr Diet 13, 149-162. 